\author{
V. V. Panteleeva, A. B. Shein, O. Yu. Kamenschikov \\ Perm state national research University, Russia, \\ 614990, Perm, Bukireva St., 15 \\ E-mail:vikpant@mail.ru; ashein@psu.ru
}

\title{
The impedance of anodic processes on passive NiSi-electrode in sulfuric fluoride containing electrolyte*
}

The mechanism and kinetics of anodic oxidation of the Ni-Si electrode in solutions of $0.5 \mathrm{M} \mathrm{H}_{2} \mathrm{SO}_{4}+(0,005-0,05) \mathrm{M} \mathrm{NaF}$ in the passive state were investigated by methods of polarization and impedance measurements. The impedance spectra are interpreted on the assumption about the formation of the bilayer oxide film on the surface of the silicide nickel, the outer layer which has a porous structure. The growth of the porous layer with the increase of the electrode potential in the investigated solutions is linearly (constant anodizing is $2.2 \mathrm{~nm} / \mathrm{V}$ ). The increase in NaF concentration leads to a decrease in the thickness of the porous layer. The growth of the barrier layer of the oxide film was described in the framework of the model of point defects. The diffusion coefficient of oxygen vacancies inside the barrier layer of the film is $8.5 \cdot 10^{-16}$ $\mathrm{cm}^{2} / \mathrm{s}$ and varies weakly with the potential and the content of sodium fluoride in solution. Microscopic and profilometric studies show the development of the surface of the NiSi electrode during anodic etching.

Keywords: the method of impedance measurements; two layer oxid; metal monosilicic.

*The work is executed at financial support of RFBR under research project No. 14-03-31016.

(C) Panteleeva V. V., Shein A. B. , Kamenschikov 0. Yu., 2016

\section{Introduction}

In the study of anodic processes on the mono-silicides of metals of the iron triads in solution of $0.5 \mathrm{M} \mathrm{H}_{2} \mathrm{SO}_{4}$ was found that a factor contributing to the high chemical resistance of the passive $\mathrm{FeSi}, \mathrm{CoSi}$, and $\mathrm{NiSi}$ in sulfuric electrolyte is the surface chemically stable in acidic media film, similar in composition to $\mathrm{SiO}_{2}$, for which characteristics such as impedance, electrical resistance, resistivity and uniformity have a maximum value approximately in the middle of the passivation field [1-4].

However, when the content in the solution of hydrofluoric acid or its salts passivation influence of silicon dioxide is weakened: fluosilicic acid or a soluble ferrosilicates [4-7] are formed in the interaction of $\mathrm{SiO}_{2}$ with $\mathrm{HF}$ or F-ions. The aim of the present study is to examine the concentration effect of sodium fluoride on the kinetics and mechanism of anodic 
oxidation of the NiSi electrode in sulfuric acid solution in the passive state.

\section{Experimental technique}

The material for investigation was monosilicic nickel, which was obtained by the Czochralski method from a silicon KPZ-1 (99.99 wt. \% Si) and electrolytic nickel N-0 (99.99 wt. \% Ni). The electrochemical measurements were performed in solutions of $0.5 \mathrm{M} \mathrm{H}_{2} \mathrm{SO}_{4}+(0,005-$ $0,05) \mathrm{M} \mathrm{NaF}$ at room temperature ( 20 $22{ }^{\circ} \mathrm{C}$ ) in conditions of natural aeration in the fluoroplastic cell using a potentiostatgalvanostat with built-in frequency analyzer Solartron 1280C (Solartron Analytical).

For the preparation of solutions the deionised water was used (resistivity $18.2 \mathrm{MOhm} \cdot \mathrm{cm}$ ) and reagents $\mathrm{H}_{2} \mathrm{SO}_{4}$ of brand "c.p." and $\mathrm{NaF}$ of brand "c.f.a". All potentials in this work are presented in comparison to the normal hydrogen electrode. Before measurement the working electrode surface was polished with abrasive papers with consequent reduction of grain size, degreased with etha- nol, rinsed with working solution. After immersion in the solution the electrode was held at open-circuit potential before the establishment of the stationary value of the potential, then the current-voltage curves and impedance spectra were took. The range of frequency $f(\omega / 2 \pi)$ used in the impedance measurement was from 20 $\mathrm{kHz}$ to $(0,005-0,002) \mathrm{Hz}$, the amplitude of the AC signal was (10 to 20 ) $\mathrm{mV}$.

The morphology of the sample surface before and after electrochemical testing was examined using a scanning electron microscope S-3400N (Hitachi). The images were obtained in a high vacuum at an accelerating voltage of $10 \mathrm{kV}$ in the mode scattering of secondary electrons.

The study of micro-roughness of the electrode surface was carried out at the interference microscope - non-contact profilometer “New View 5000” (Zygo).

\section{Results and discussion}

The anodic potentiostatic curves of $\mathrm{NiSi}$ electrode in solutions of $0.5 \mathrm{M} \mathrm{H}_{2} \mathrm{SO}_{4}$ $+(0-0,05) \mathrm{M} \mathrm{NaF}$ are shown in Fig.1. In the potential range from 0.40 to $1.70 \mathrm{~V}$, corresponding to the passive state, the polarization curves of NiSi there is a noticeable growth of $i$ with increasing electrode polarization and with increasing the content of sodium fluoride in solution.

In the passive potential state, the impedance hodographs NiSi electrode in the investigated solutions consist of the capacitive semicircle at high frequencies and of the inclined line at low frequencies (Fig. 2).
The equivalent electric circuit describing the presence on the surface of the electrode the double-layer passivating film, consisting of an inner barrier and outer porous layers (Fig. 3) was used for the simulation of impedance spectra of NiSi (Fig. 2). The film growth is associated with the transfer of the defects inside the barrier layer, which through the pores of the outer layer the electrolyte is accessed. At the interface of the barrier layer/electrolyte interface as a result of interaction of the substance of the oxide film with hydrofluoric acid is place of its partial transition to the solution and the 
formation of pores. In the circuit in Fig. 3: $\mathrm{R}_{\mathrm{s}}$ is resistance of the electrolyte between the spout of the capillary Loggia and the working electrode surface, $R_{1}$ is the resistance of the electrolyte in the pores of the outer layer, $\mathrm{R}_{2}$ is the resistance of charge transfer, $Z_{d}$ is the Warburg impedance describing the migration of defects within the barrier layer, the elements of constant phase $\mathrm{CPE}_{1}$ and $\mathrm{CPE}_{2}$ are modeling the heterogeneous capacity of the outer layer of an oxide film and boundary barrier layer/electrolyte interface, respectively.

The parameter $\chi^{2}$ for the equivalent circuit in Fig. 3 takes values $(8-20) \cdot 10^{-5}$, which show a good correlation between the model and experimental data.

It follows from calculated by the equivalent circuit data in Fig. 3, while developing the capacity NiSi electrode in all solutions investigated, the thickness of the outer porous layer increases with E, approximately linearly, with the increase of porosity outstripping the growth of the

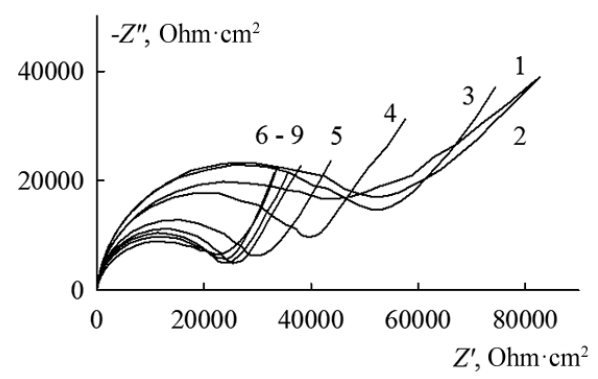

Fig. 1. Anodic potentiostatic curves of $\mathrm{NiSi}$ in $0.5 \mathrm{M} \mathrm{H}_{2} \mathrm{SO}_{4}+\mathrm{NaF}, \mathrm{M}: 1-0 ; 2-0,005$; $3-0,01 ; 4-0,02 ; 5-0,05$

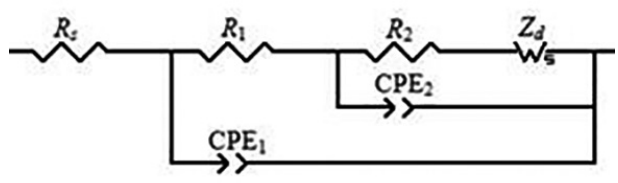

Fig. 3. An equivalent electric circuit for $\mathrm{NiSi}$ in $0.5 \mathrm{M} \mathrm{H}_{2} \mathrm{SO}_{4}+(0,005-0,05) \mathrm{M}$ $\mathrm{NaF}$ in the passive state layer thickness. Under the assumption that the basis of oxide film on the surface of the silicide of nickel in fluoride containing electrolyte is $\mathrm{NiO}$ (or hydrated oxide of $\mathrm{Ni}(\mathrm{OH})_{2}$ ), estimated the thickness $d$ of the porous layer of the oxide film: constant growth $(\mathrm{K}=\mathrm{dd} / \mathrm{dE})$ of the porous layer of the oxide film in the potential range from 0.8 to $1.6 \mathrm{~V}$ equal to $2.2 \mathrm{~nm}$ (the thickness of the porous layer varies from 3.2 to 5.0 $\mathrm{nm}$ for solutions with different concentrations of $\mathrm{NaF}$ ). If we assume that the passive film is a mixed oxide and along with the nickel oxide also contains a certain amount of silicon dioxide, the constant anodizing will be somewhat less. The increasing of the concentration of sodium fluoride leads to a slight reduction in the thickness of the porous layer of the oxide film that, apparently, is connected with the dissolution of the substance of the film in the presence of HF. The thickness of the barrier layer also increases with increasing E. The coefficient of the diffusion of oxygen vacancies D inside barrier layer of the passivating film on

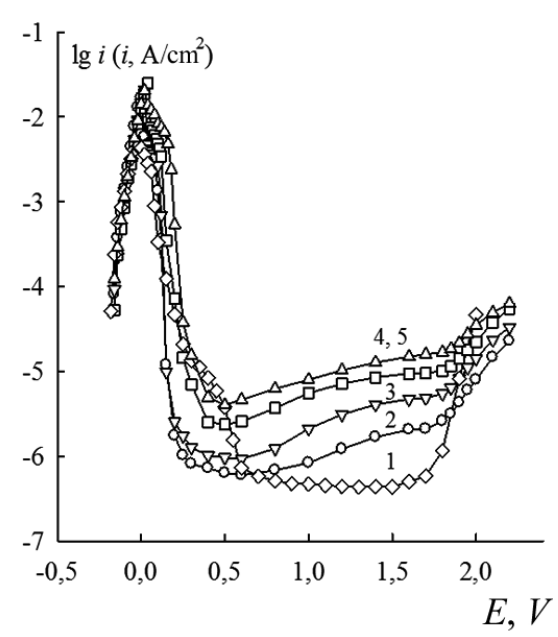

Fig. 2. Impedance spectra NiSi in $0.5 \mathrm{M}$

$\mathrm{H}_{2} \mathrm{SO}_{4}+0.02 \mathrm{M} \mathrm{NaF}$ at E, In: $1-0,40$;

$2-0,50 ; 3-0,60 ; 4-0,80 ; 5-1,00 ; 6-1,20$;

$7-1,40 ; 8-1,60 ; 9-1,70$ 


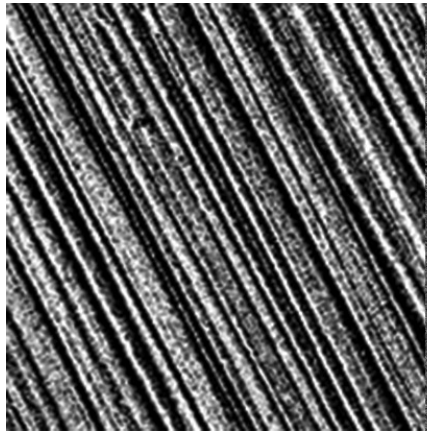

$a$

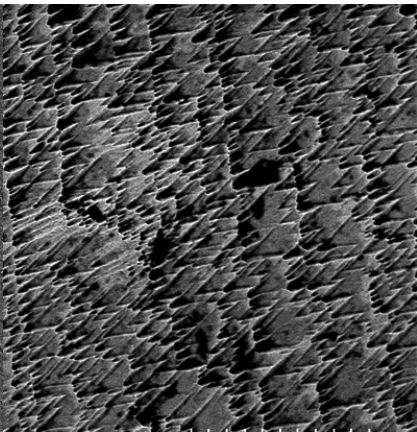

$v C$

Fig. 4. Photomicrographs of the surface of the $\mathrm{NiSi}(\times 700)$ before (a) and after anodic etching in $0.5 \mathrm{M} \mathrm{H}_{2} \mathrm{SO}_{4}$ (b) and $0.5 \mathrm{M} \mathrm{H}_{2} \mathrm{SO}_{4}+0.05 \mathrm{M} \mathrm{NaF}$ (b) at E $=1.2 \mathrm{~V}$

the $\mathrm{NiSi}$ in the solution of $0.5 \mathrm{M} \mathrm{H}_{2} \mathrm{SO}_{4}+$ $0,02 \mathrm{M} \mathrm{NaF}$ at $\mathrm{E}=1.2 \mathrm{~V}$ is $8.5 \cdot 10-16 \mathrm{~cm}^{2} / \mathrm{s}$ and varies weakly with increasing electrode polarization and the content of sodium fluoride in solution. A slight increase of the diffusion coefficient (but very weak) when the concentration of sodium fluoride in solution, probably due to the increase of defects in the structure of the barrier layer film formed in the presence of fluoride.

The microscopic examination $\mathrm{NiSi}$ before and after electrochemical testing shows that the anodic etching of silicide at $\mathrm{E}$ the passive condition in $0.5 \mathrm{M} \mathrm{H}_{2} \mathrm{SO}_{4}$ $+0.05 \mathrm{M} \mathrm{NaF}$ leads to a significant development of the electrode surface (Fig. 4 presents the comparison of photographs of the electrode surface before and after anodic etching in bestrides and fluoride containing solutions).
The development of the surface of the electrode in sulfuric non-fluoride electrolyte may be due to restroom in the potential region of active dissolution and of active-passive transition. The introduction to the solution of sodium fluoride leads to an even more substantial irritation of the electrode surface due to dissolution of the oxides $\mathrm{NiO}$ and $\mathrm{SiO}_{2}$ in the presence of fluoride formed during anodic oxidation of NiSi in the passive state.

The results of measurement of microroughness of the surface of the NiSi electrode fully correlate with the microscopic studies.

The values of $\mathrm{R}_{\mathrm{a}}$ and rms change as follows: $\mathrm{R}_{\mathrm{a}}(\mathrm{nm}) / \mathrm{rms}(\mathrm{nm})=25,5 / 34,3$ (initial sample) : 79,8/119.4 $\mathrm{p}$ (anodic etching in $0.5 \mathrm{M} \mathrm{H}_{2} \mathrm{SO}_{4}$ at $\left.\mathrm{E}=1.2 \mathrm{~V}\right): 957,5 / 1240,8$ (anodic etching in $0.5 \mathrm{M} \mathrm{H}_{2} \mathrm{SO}_{4}+0.05 \mathrm{M}$ $\mathrm{NaF}$ at $\mathrm{E}=1.2 \mathrm{~V})$.

\section{Conclusion}

The investigation of the anodic behavior of NiSi electrode in sulfuric electrolyte containing a variable amount of hydrofluoric acid shows that the presence of $\mathrm{HF}$ in solution exerts a strong influence on current-voltage and impedance cha- racteristics of the silicide. The latter is evident in the substantial weakening of the passivating action of oxygen-containing compounds of the alloy components and activation NiSi of dissolution. 
1. Panteleeva V. V., Shein A. B. CoSi impedance of the electrode in sulfuric acid solution. Izv. Vyssh. Uchebn. Zaved. Khim. Khim. Tekhnol. 2012;55(7):35-39.

2. Panteleeva V. V., Shein A. B. The impedance of anodic processes on FeSi electrode in sulfuric acid solution. Izv. Vyssh. Uchebn. Zaved., Khim. Khim. Tekhnol. 2013;56(10):48-52.

3. Panteleeva V. V., Shein A. B. Growth of anodic oxide films on iron-triad metal monosilicides in sulfuric acid electrolyte. Russian J. Electrochemistry. 2014;50(11):1036-1043. doi: 10.1134/s102319351411007X.

4. Shein A. B. Elektrokhimia silicidov i germanidov perehodnih metallov, Perm, Perm. Gos. Univ. 2009:269 pp. (in Russian).

5. Batenkov V. A. Elektrokhimia poluprovodnikov. Barnaul, Alt. Gos. Univ. 2002:162 pp. (in Russian).

6. Panteleeva V. V., Shein A. B. The anodic dissolution of monosilicide iron in sulfuric acid electrolyte containing sodium fluoride. Vestn. Tamb. Univ. Estestv. Techn. Nauk. 2013;18(5):2237-2240.

7. Remi G. Kurs neorganicheskoj khimii. Moscow. 1972:824 pp. (in Russian). 
В. В. Пантелеева, А. Б. Шеин, О. Ю. Каменщиков

Пермский государственный национальный исследовательский университет Россия, 614990, Пермь, ул. Букирева, 15 E-mail:vikpant@mail.ru; ashein@psu.ru

\section{Импеданс анодных процессов на пассивном NiSi-электроде в сернокислом фторидсодержащем электролите*}

Методами поляризационных и импедансных измерений исследованы механизм и кинетика анодного окисления NiSi-электрода в раствоpax 0,5 $\mathrm{M} \mathrm{H}_{2} \mathrm{SO}_{4}+(0,005-0,05) \mathrm{M} \mathrm{NaF}$ в области пассивного состояния. Спектры импеданса интерпретированы в предположении о формировании на поверхности силицида никеля двухслойной оксидной пленки, внешний слой которой имеет пористое строение. Рост пористого слоя при повышении потенциала электрода в исследованных растворах осуществляется по линейному закону (константа анодирования составляет 2,2 нм/В). Увеличение концентрации $\mathrm{NaF}$ приводит к снижению толщины пористого слоя. Рост барьерного слоя оксидной пленки описан в рамках модели точечных дефектов. Коэффициент диффузии кислородных вакансий внутри барьерного слоя пленки составляет $8,5 \cdot 10^{-16} \mathrm{~cm}^{2} /$ с и слабо изменяется с потенциалом и содержанием фторида натрия в растворе. Микроскопические и профилометрические исследования свидетельствуют о развитии поверхности NiSi-электрода в ходе анодного травления.

\footnotetext{
Ключевые слова: метод импедансных измерений; двухслойная оксидная пленка; моносилициды металлов.

* Работа выполнена при финансовой поддержке РФФИ в рамках научного проекта № 14-03-31016 мол_а.

(C) Пантелеева В. В., Шеин А. Б., Каменщиков О. Ю., 2016
}

\section{Введение}

При изучении анодных процессов на моносилицидах металлов триады железа в растворе 0,5 $\mathrm{M} \mathrm{H}_{2} \mathrm{SO}_{4}$ было установлено, что фактором, обусловливающим высокое химическое сопротивление пассивных $\mathrm{FeSi}, \mathrm{CoSi}$ и $\mathrm{NiSi}$ в сернокислом электролите, явля- ется поверхностная химически стойкая в кислых средах пленка, близкая по составу к $\mathrm{SiO}_{2}$, для которой такие характеристики, как импеданс, электрическое сопротивление, удельное сопротивление и однородность имеют 
максимальные значения примерно в середине области пассивации [1-4].

Однако при содержании в растворе фтороводородной кислоты или ее солей пассивационное влияние диоксида кремния ослабляется: при взаимодействии $\mathrm{SiO}_{2}$ с $\mathrm{HF}$ или $\mathrm{F}^{-}$-ионами образуются кремнефтористоводородная кислота или растворимые фторосиликаты [4-7].

Целью настоящего исследования является изучение концентрационного влияния фторида натрия на кинетику и механизм анодного окисления $\mathrm{NiSi}$ электрода в растворе серной кислоты в области пассивного состояния.

\section{Методика эксперимента}

Материалом для исследования служил моносилицид никеля, который был получен методом Чохральского из кремния КПЗ-1 (99,99 мас. \% $\mathrm{Si})$ и электролитического никеля Н-0 (99,99 мас. \% Ni).

Электрохимические измерения проводили в растворах 0,5 М $\mathrm{H}_{2} \mathrm{SO}_{4}+(0,005-0,05) \mathrm{M} \mathrm{NaF}$ при комнатной температуре ( 20-22 $\left.{ }^{\circ} \mathrm{C}\right)$ в условиях естественной аэрации во фторопластовой ячейке с помощью потенциостата-гальваностата с встроенным частотным анализатором Solartron 1280C (Solartron Analytical). Для приготовления растворов использовали деионизованную воду (удельное сопротивление 18,2M Ом · см) и реактивы $\mathrm{H}_{2} \mathrm{SO}_{4}$ марки «х.ч.» и $\mathrm{NaF}$ марки «ч.д.а.». Все потенциалы в работе приведены относительно нормального водородного электрода.

Перед проведением измерений рабочую поверхность электрода шлифовали абразивными бумагами с последовательным уменьшением размера зерна, обезжиривали этиловым спиртом, ополаскивали рабочим раствором. После погружения в раствор электрод выдерживали при потенциале разомкнутой цепи до установления стационарного значения потенциала, далее снимали вольтамперные кривые и спектры импеданса. Диапазон используемых в импедансных измерениях частот $f(\omega / 2 \pi)$ - от 20 кГц до (0,005-0,002) Гц - амплитуда переменного сигнала (10-20) мВ.

Морфологию поверхности образца до и после электрохимических испытаний исследовали с помощью сканирующего электронного микроскопа S-3400N (Hitachi). Изображения были получены в высоком вакууме при ускоряющем напряжении 10 кВ в режиме рассеяния вторичных электронов.

Исследование микрошероховатости поверхности электрода осуществляли на интерференционном микроскопе - бесконтактном профилометре New View-5000 (Zygo).

\section{Результаты и их обсуждение}

Анодные потенциостатические кривые $\mathrm{NiSi-электрода} \mathrm{в} \mathrm{растворах}$ 0,5 $\mathrm{M} \mathrm{H}_{2} \mathrm{SO}_{4}+(0-0,05) \mathrm{M} \mathrm{NaF}$ приведены на рис. 1. При потенциалах от 0,40 до $1,70 \mathrm{~B}$, соответствующих области пассивного состояния, на поляризационных кривых NiSi наблюдается заметный рост і с увеличением поляризации электрода и с повышением содержания фторида натрия в растворе. 
В области потенциалов пассивного состояния годографы импеданса $\mathrm{NiSi}$ электрода в исследованных растворах состоят из полуокружности емкостного типа при высоких частотах и наклонной прямой при низких частотах (рис. 2).

Для моделирования спектров импеданса $\mathrm{NiSi}$ (рис. 2) использована эквивалентная электрическая схема, описывающая присутствие на поверхности электрода двухслойной пассивирующей пленки, состоящей из внутреннего барьерного и внешнего пористого слоев (рис. 3). Рост пленки сопряжен с переносом дефектов внутри барьерного слоя, к которому через поры внешнего слоя осуществляется доступ электролита. На границе раздела барьерный слой/электролит в результате взаимодействия вещества оксидной пленки с фтороводородной кислотой происходит его частичный переход в раствор и формированиепор. В схеме на рис. 3: $R_{s}$ - сопротивление электролита между носиком капилля-

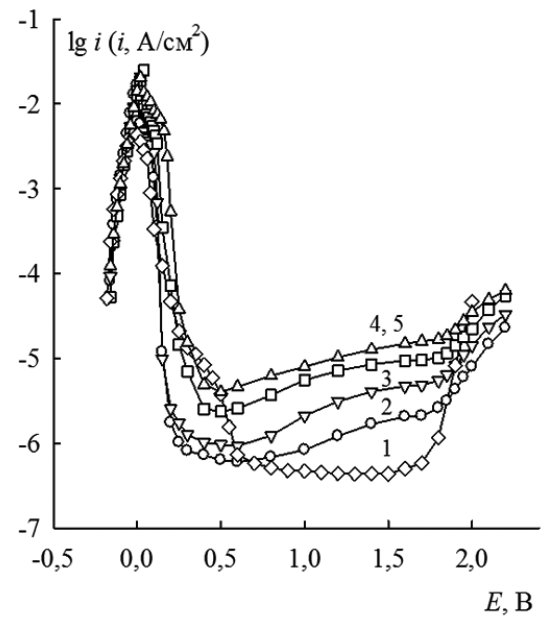

Рис. 1. Анодные потенциостатические кривые $\mathrm{NiSi}$ в $0,5 \mathrm{M} \mathrm{H}_{2} \mathrm{SO}_{4}+\mathrm{NaF}, \mathrm{M}$ : $1-0 ; 2-0,005 ; 3-0,01 ; 4-0,02 ; 5-0,05$ ра Луггина и рабочей поверхностью электрода; $R_{1}$ - сопротивление электролита в порах внешнего слоя; $R_{2}-$ сопротивление переноса заряда; $Z_{d}-$ импеданс Варбурга, описывающий перенос дефектов внутри барьерного слоя, элементы постоянной фазы $\mathrm{CPE}_{1}$ и $\mathrm{CPE}_{2}$ моделируют емкость неоднородного внешнего слоя оксидной пленки и границы раздела барьерный слой/электролит, соответственно.

Параметр $\chi^{2}$ для эквивалентной схемы на рис. 3 принимает значения $(8-20) \cdot 10^{-5}$, что говорит о хорошей корреляции между моделью и экспериментальными данными.

Из расчитанных по эквивалентной схеме на рис. 3 данных следует, что при повышении потенциала NiSi-электрода во всех исследованных растворах толщина внешнего пористого слоя увеличивается с Е примерно по линейному закону, при этом рост пористости

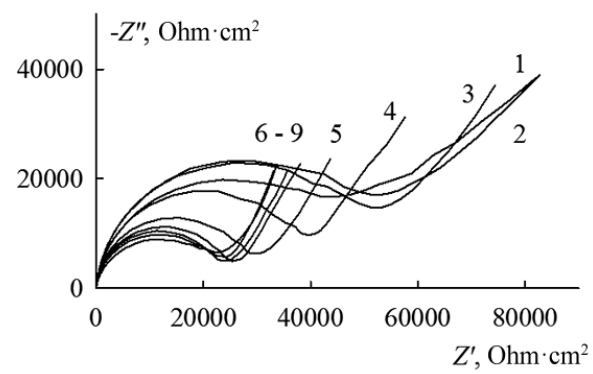

Рис. 2. Спектры импеданса NiSi в $0,5 \mathrm{M}$ $\mathrm{H}_{2} \mathrm{SO}_{4}+0,02 \mathrm{M} \mathrm{NaF}$ при Е, B: 1 - 0,40; $2-0,50 ; 3-0,60 ; 4-0,80 ; 5-1,00 ; 6-1,20$; $7-1,40 ; 8-1,60 ; 9-1,70$

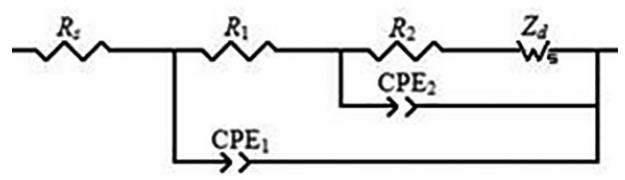

Рис. 3. Эквивалентная электрическая схема для $\mathrm{NiSi}$ в $0,5 \mathrm{M} \mathrm{H}_{2} \mathrm{SO}_{4}+(0,005-0,05) \mathrm{M}$ $\mathrm{NaF}$ в области пассивного состояния 
опережает рост толщины слоя. В предположении, что основу оксидной пленки на поверхности силицида никеля во фторидсодержащем электролите составляет $\mathrm{NiO}$ (или гидратированный оксид $\left.\mathrm{Ni}(\mathrm{OH})_{2}\right)$, оценена толщина $d$ пористого слоя оксидной пленки: постоянная роста $(\mathrm{K}=\mathrm{dd} / \mathrm{dE})$ пористого слоя оксидной пленки в интервале потенциалов от 0,8 до 1,6 В равна 2,2 нм/В (толщина пористого слоя при этом изменяется от 3,2 до 5,0 нм для растворов с разным содержанием $\mathrm{NaF}$ ). Если допустить, что пассивная пленка представляет смешанный оксид и наряду с оксидом никеля также содержит некоторое количество диоксида кремния, то константа анодирования окажется несколько меньше. Повышение концентрации фторида натрия приводит к небольшому снижению толщины пористого слоя оксидной пленки, что, по-видимому, связано с растворением вещества пленки в присутствии HF. Толщина барьерного слоя также повышается с ростом Е. Коэффициент диффузии кислородных вакансий D внутри барьерного слоя пассивирующей пленки на $\mathrm{NiSi}$ в растворе $0,5 \mathrm{M} \mathrm{H}_{2} \mathrm{SO}_{4}+$
$+0,02 \mathrm{M} \mathrm{NaF}$ при $\mathrm{E}=1,2$ В составляет $8,5 \cdot 10^{-16} \mathrm{~cm}^{2} /$ с и слабо изменяется с ростом поляризации электрода и содержанием фторида натрия в растворе. Небольшое увеличение коэффициента диффузии (однако весьма слабое) при повышении концентрации фторида натрия в растворе, вероятно, связано с ростом дефектности структуры барьерного слоя пленки, образуемой в присутствии фторида.

Микроскопическое исследование $\mathrm{NiSi}$ до и после электрохимических испытаний показывает, что анодное травление силицида при Е области пассивного состояния в $0,5 \mathrm{M} \mathrm{H}_{2} \mathrm{SO}_{4}+$ $+0,05 \mathrm{M} \mathrm{NaF}$ приводит к значительному развитию электродной поверхности (на рис. 4 для сравнения представлены фотографии поверхности электрода до и после анодного травления в бесфторидном и фторидсодержащем раствоpax).

Развитие поверхности электрода в сернокислом бесфторидном электролите может быть обусловлено растравом при потенциалах области активного растворения и активно-пассивного перехода. Введение в раствор фторида

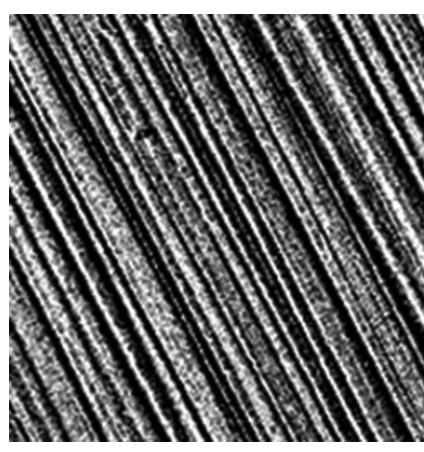

$a$

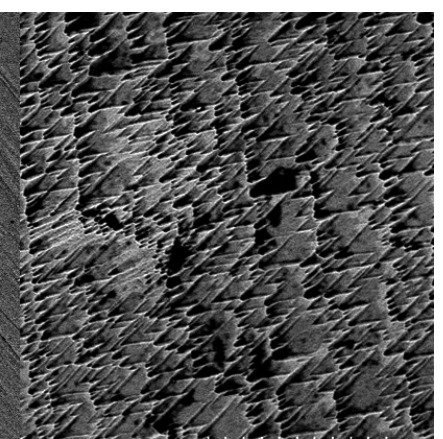

B

Рис. 4. Микрофотографии поверхности $\mathrm{NiSi}(\times 700)$ до (a) и после анодного травления в $0,5 \mathrm{M} \mathrm{H}_{2} \mathrm{SO}_{4}$ (б) и $0,5 \mathrm{M} \mathrm{H}_{2} \mathrm{SO}_{4}+0,05 \mathrm{M} \mathrm{NaF}$ (в) при $\mathrm{E}=1,2 \mathrm{~B}$ 
натрия приводит к еще более существенному растравливанию электродной поверхности, что обусловлено растворением в присутствии фторида образующихся при анодном окислении $\mathrm{NiSi}$ в области пассивного состояния оксидов $\mathrm{NiO}$ и $\mathrm{SiO}_{2}$.

Результаты измерения параметров микрошероховатости поверхности
$\mathrm{NiSi-электрода} \mathrm{полностью} \mathrm{коррелиру-}$ ют с данными микроскопических исследований. Значения $R_{a}$ и rms изменяются следующим образом: $R_{a}(\mathrm{Hм}) / \mathrm{rms}(\mathrm{Hм})=$ $=25,5 / 34,3$ (исходный образец): $79,8 / 119,4$ (анодное травление в 0,5 M $\mathrm{H}_{2} \mathrm{SO}_{4}$ при $\mathrm{E}=1,2 \mathrm{~B}$ ) : 957,5/1240,8 (анодное травление в $0,5 \mathrm{M} \mathrm{H}_{2} \mathrm{SO}_{4}+0,05 \mathrm{M}$ $\mathrm{NaF}$ при $\mathrm{E}=1,2 \mathrm{~B}$ ).

\section{Заключение}

Исследование анодного поведения $\mathrm{NiSi-электрода} \mathrm{в} \mathrm{сернокислом} \mathrm{элект-}$ ролите, содержащем переменное количество фтороводородной кислоты, показывает, что присутствие HF в растворе оказывает достаточно сильное влияние на вольтамперные и импеданс- ные характеристики силицида. Последнее проявляется в существенном ослаблении пассивирующего действия кислородсодержащих соединений компонентов сплава и активации растворения $\mathrm{NiSi}$.

1. Panteleeva V. V., Shein A. B. Impedance of CoSi-electrode in sulphuric acid solution. Izv. Vyssh. Uchebn. Zaved. Khim. Khim. Tekhnol. 2012;55(7):35-40.

2. Panteleeva V. V., Shein A. B. Impedance of anodic processes on FeSi-electrode in sulphuric acid solution. Izv. Vyssh. Uchebn. Zaved., Khim. Khim. Tekhnol. 2013;56(10):48-53.

3. Panteleeva V. V., Shein A. B. Growth of anodic oxide films on iron-triad metal monosilicides in sulfuric acid electrolyte. Russian J. Electrochemistry. 2014;50(11):1036-1043. DOI: 10.1134/s102319351411007X. 1.

4. Shein A. B. Elektrokhimia silicidov i germanidov perehodnih metallov. Perm: Perm. Gos. Univ., 2009. 269 pp. (in Russian).

5. Batenkov V. A. Elektrokhimia poluprovodnikov. Barnaul: Alt. Gos. Univ., 2002. 162 pp. (in Russian).

6. Panteleeva V. V., Shein A. B. Anodic dissolution of iron silicide in sulfuric acid solution, containing sodium fluoride. Vestn. Tamb. Univ. Estestv. Techn. Nauk. 2013;18(5):2237-2240.

7. Remi G. Kurs neorganicheskoj khimii. Moscow, 1972. 824 pp. (in Russian). 